\title{
Diffuse cutaneous reaction following PPV-23 pneumococcal vaccine: an immunisation-associated hypersensitivity vasculitis
}

\author{
Abuelmagd Abdalla @ , , Salim Sebaoui, ${ }^{2}$ Shafeeq Alraqi ${ }^{1}$
}

${ }^{1}$ Rheumatology, Mater Misericordiae University Hospital, Dublin 7, Ireland ${ }^{2}$ Acute Medicine, Mater Misericordiae University Hospital, Dublin 7, Ireland

\section{Correspondence to} Dr Abuelmagd Abdalla; dr_abuelmagd@icloud.com

Accepted 4 March 2020

\section{DESCRIPTION}

A 76-year-old man attended our emergency department with a 7-day history of skin rash and itchiness and was subsequently admitted to the hospital with a possible small vessel vasculitis. On further questioning, he admitted receiving a pneumococcal vaccine for the first time 3 days before his symptoms. He also received his seasonal influenza vaccine simultaneously, which he had received regularly for the past 10 years without any reactions. He denied any other specific symptoms besides his rash, which started around the injection site then eventually spread to most of his body (sparing the head and neck). He had a background of chronic obstructive pulmonary disease, hypertension, atrial fibrillation and a metallic aortic valve in addition to active smoking. His medications remained unchanged for the preceding 2 years.

His clinical examination established normal vital signs without fever or distress. His skin examination revealed diffuse rash to all his limbs and torso (figures 1-3). The cutaneous eruption was a combination of maculopapular, petechial, purpuric and ecchymotic lesions with few scattered haemorrhagic blisters. Few necrotic lesions also noted to his right middle finger (figure 1B).

His laboratory work revealed neutrophil leucocytosis, elevated C-reactive protein and mildly reduced lymphocytes and eosinophils. The autoimmune and viral screening was negative, including normal immunoglobulins and complements levels in the absence of circulating cryoglobulins. Urine examination showed no red cells or protein. His skin biopsy (punch) revealed marked papillary dermal oedema and prominent superficial and middermal perivascular lymphocytic infiltration with numerous eosinophils but negative direct immunofluorescence. The findings were felt to be consistent with dermal hypersensitivity response to a possible

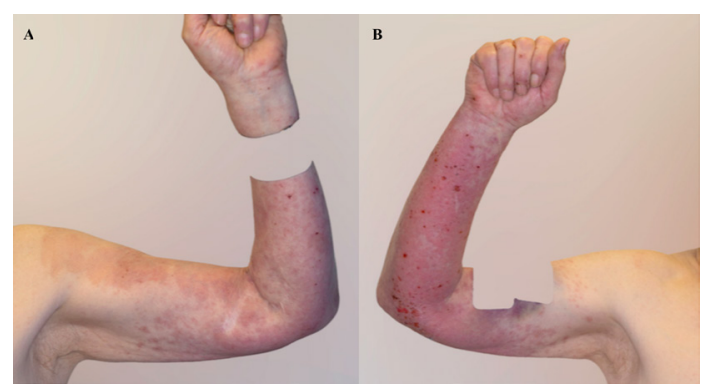

Figure 1 Both upper limbs left (A) and right (B).

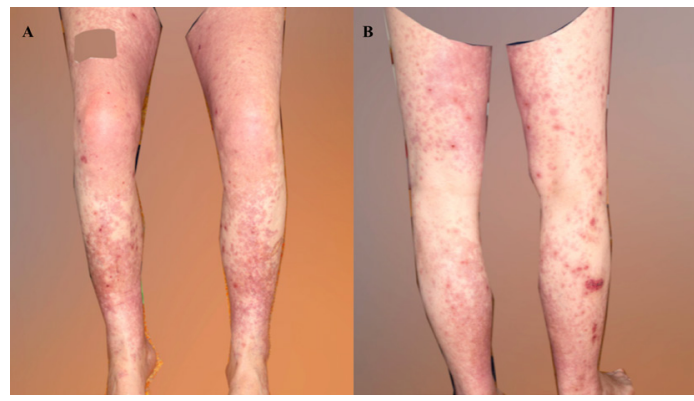

Figure 2 Both lower limbs front (A) and back (B).

drug reaction, which in this case, the pneumococcal vaccine was the most probable trigger given the sequence of events and the absence of other precipitants. The patient received $40 \mathrm{mg}$ prednisolone daily and $10 \mathrm{mg}$ cetirizine, which led to significant clinical improvement.

Pneumococcal polysaccharide vaccine contains 23 of the most prevalent and invasive pneumococcal strains (Pneumovax 23). Hypersensitivity vasculitis is a cutaneous small vessel vasculitis mediated through immune complex deposition that is triggered by different factors such as drugs, infections, neoplasm or in association with other inflammatory conditions or connective tissue diseases. ${ }^{1}$ However, the cause may remain unclear in about $30 \%-50 \%$ of cases. ${ }^{2}$

The diagnosis is usually secured with a punch biopsy of a fresh lesion ideally between 24-48-hour-old for histopathology, and 8-24-hour-old for direct immunofluorescence. ${ }^{3}$ A 2014 population-based study in the USA had estimated an incidence of 45 cases per million per year. ${ }^{4}$ Various vasculitides were reported in association with numerous vaccinations, classically cutaneous vasculitis and commonly within 10 days. ${ }^{5}$ Severe forms of systemic vasculitis after

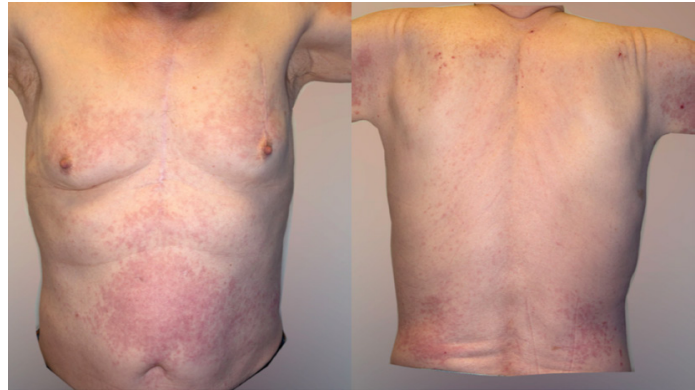

Figure 3 Front and back of the torso. 
pneumococcal vaccine had also been reported, including Kawasaki disease, polymyalgia rheumatica, CNS vasculitis and type II mixed cryoglobulinemia. ${ }^{67}$ Moreover, few reports had emerged on the risk of inducing severe local and systemic reactions as well as a disease flare to stable patients with Behcet's disease triggered by pneumococcal vaccine, ${ }^{89}$ a cohort typically strongly encouraged to receive immunisation against vaccine-preventable infections. $^{10}$

\section{Learning points}

- Vasculitis secondary to immunisation is uncommon but increasingly reported and should be considered in the differential diagnosis of possible drug reactions.

- While immunisation is recommended for subgroups including elderly patients with multi-comorbidities, it can sometimes lead to significant morbidity.

Acknowledgements Department of clinical photography, The Mater Misericordiae University Hospital.

Contributors AA and SS drafted the manuscript; SA revised and approved the script. All authors shared the clinical care of this patient.

Funding The authors have not declared a specific grant for this research from any funding agency in the public, commercial or not-for-profit sectors.

Competing interests None declared.

Patient consent for publication Obtained.
Provenance and peer review Not commissioned; externally peer reviewed.

\section{ORCID iD}

Abuelmagd Abdalla http://orcid.org/0000-0002-5596-4726

\section{REFERENCES}

1 Kevil CG, Bullard DC. Roles of leukocyte/endothelial cell adhesion molecules in the pathogenesis of vasculitis. Am J Med 1999;106:677-87.

2 Patel-Cohen M. Hypersensitivity vasculitis: background, pathophysiology, etiology, 2018. Available: https://emedicine.medscape.com/article/1083719-overview\#a7

3 Demirkesen C. Approach to cutaneous vasculitides with special emphasis on small vessel vasculitis. Curr Opin Rheumatol 2017;29:39-44.

4 Arora A, Wetter DA, Gonzalez-Santiago TM, et al. Incidence of leukocytoclastic vasculitis, 1996 to 2010: a population-based study in Olmsted County, Minnesota. Mayo Clin Proc 2014;89:1515-24.

5 Bonetto C, Trotta F, Felicetti P, et al. Vasculitis as an adverse event following immunization - systematic literature review. Vaccine 2016;34:6641-51.

6 Felicetti P, Trotta F, Bonetto C, et al. Spontaneous reports of vasculitis as an adverse event following immunization: a descriptive analysis across three international databases. Vaccine 2016;34:6634-40

7 Eid S, Callen JP. Type II mixed cryoglobulinemia following influenza and pneumococcal vaccine administration. JAAD Case Rep 2019;5:960-2.

8 Hügle T, Bircher A, Walker UA. Streptococcal hypersensitivity reloaded: severe inflammatory syndrome in Behcet's disease following 23-valent polysaccharide Streptococcus pneumoniae vaccine. Rheumatology 2012;51:761-2.

9 Saeidinejad M, Kardash S, Connell L. Behcet's disease and severe inflammatory reaction to 23-valent pneumococcal polysaccharide vaccine: a case report and review of literature. Scott Med J 2018:119-21.

10 Furer V, Rondaan C, Heijstek MW, et al. 2019 update of EULAR recommendations for vaccination in adult patients with autoimmune inflammatory rheumatic diseases. Ann Rheum Dis 2020;79:39-52.

Copyright 2020 BMJ Publishing Group. All rights reserved. For permission to reuse any of this content visit https://www.bmj.com/company/products-services/rights-and-licensing/permissions/

BMJ Case Report Fellows may re-use this article for personal use and teaching without any further permission.

Become a Fellow of BMJ Case Reports today and you can:

- Submit as many cases as you like

- Enjoy fast sympathetic peer review and rapid publication of accepted articles

- Access all the published articles

Re-use any of the published material for personal use and teaching without further permission

\section{Customer Service}

If you have any further queries about your subscription, please contact our customer services team on +44 (0) 2071111105 or via email at support@bmj.com.

Visit casereports.bmj.com for more articles like this and to become a Fellow 